\title{
Study of the potential employment of Malvaceae Species in composites materials
}

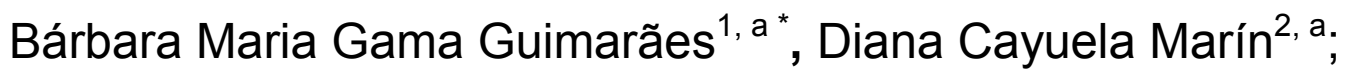 \\ Welton Fernando Zonatti ${ }^{3, b}$, Waldir Mantovani ${ }^{3, c}$, Cátia Relvas ${ }^{4, d}$, \\ Fernando Cunha ${ }^{4, e}$, Raul Fangueiro ${ }^{4, f}$, Holmer Savastano Júnior ${ }^{1, g}$ \\ and Júlia Baruque-Ramos ${ }^{3, h}$
}

\author{
${ }^{1}$ Av. Duque de Caxias Norte, 225 - 13635-900 - Pirassununga/SP - Brazil. \\ ${ }^{2}$ Carrer de Colom, 15, 08222. Terrassa, Barcelona. Barcelona - Spain \\ ${ }^{3}$ Av. Arlindo Béttio, 1000. Ermelino Matarazzo.03828-000 São Paulo, SP - Brazil \\ ${ }^{4}$ UMinho - Campus de Azurém, 4800-058. Guimarães. Portugal. \\ abarbara.guimaraes@usp.br, 'belton@usp.br, 'wmantova@usp.br, ${ }^{\mathrm{d}}$ catiarelvas@civil.uminho.pt, \\ efernandocunha@det.uminho.pt, 'rfangueiro@civil.uminho.pt, ${ }^{9}$ holmersj@usp.br, \\ hibaruque@usp.br
}

Keywords: Malvaceae, vegetal fiber, physicochemical characterization, composites.

\begin{abstract}
The employ of vegetal fibers for textiles and composites represents a great potential in economic and social sustainable development. Some Malvaceae species are considered tropical cosmopolitans, such as from Sida genus. Several species of this genus provide excellent textile bast fibers, which are very similar in qualities to the jute textile fiber. The objective of the present study is present the physicochemical characterization of six Brazilian vegetal fibers: Sida rhombifolia L.; Sida carpinifolia L. f.; Sidastrum paniculatum (L.) Fryxell; Sida cordifolia L.; Malvastrum coromandelianum (L.) Gurck; Wissadula subpeltata (Kuntze) R.E.Fries. Respectively the two first species are from Brazilian Atlantic Forest biome and the four remaining from Brazilian Cerrado biome, despite of present in other regions of the planet. The stems of these species were retted in water at $37 \mathrm{oC}$ for 20 days. The fibers were tested in order to determine tensile rupture strength, tenacity, elongation, Young's modulus, cross microscopic structure, Scanning Electronic Microscopy (SEM), regain, combustion, acid, alkali, organic solvent and cellulase effects, $\mathrm{pH}$ of the aqueous extract, Differential Scanning Calorimetry (DSC) and Thermogravimetric Analysis (TGA). The obtained values were compared with those from fibers of recognized applicability in the textile industry including hemp. The results are promising in terms of their employment in thermoset and thermoplastic medium resistance composites.
\end{abstract}

\section{Introduction}

The traditional employments of vegetal fibers are destined mainly for the production of yarns, woven fabrics, knits, nonwovens and other textiles for apparels, household items and technical textiles. On the other hand, natural vegetal fibers are becoming economic and ecological alternatives for employing as reinforcements and fillers in plastics. Vegetal fiber composite materials have found applications in construction, industry, furniture, packaging and automotive components. The employ of lignocellulosic materials as a building component in polymer composites has received increased attention, particularly because of its low price and specific weight, especially in the automotive industry [1]. There is great interest in producing vehicles with 
all recyclable or biodegradable components. Another outstanding factor is related to the reductions in cost and weight of cars [2]. Some predictions are related to the gradual replacement of traditional synthetic additives, particularly glass fibers for such materials, opening up market opportunities for farming countries. In Brazil the employ of natural vegetal fibers in automotive and construction sectors is taking new impetus, although the techniques for manufacturing these composites are still incipient, slow and little productive [1]. In addition to technological applications it is worth to mention the great importance of the traditional employ of natural fibers in handicraft. Brazil has six main biomes, namely: Amazonia, Caatinga, Pantanal, Pampa, Atlantic Forest and Cerrado. The Atlantic Forest is a terrestrial Biome and region which extends along the Atlantic coast of Brazil from Rio Grande do Norte state in the north to Rio Grande do Sul state in the south, and inland as far as Paraguay and the Misiones Province of Argentina. The Atlantic Forest is characterized by high species diversity and endemism. It was the first environment that the Portuguese colonizers encountered over 500 years ago. Currently, the Atlantic Forest spans over $4,000 \mathrm{~km} 2$ along the coast of Brazil and in a small part of Paraguay and Argentina [3].

The Cerrado is a vast tropical savanna in Brazil. This biome is the second largest of Brazil's major habitat types, after Amazonia, accounting for a full 21 percent of the country's land area (extending marginally into Paraguay and Bolivia) [4]. Despite of the great number of vegetal species, many of them have not yet been discovered or little studied. The region of District of "Cachoeira de Emas" (Pirassununga - São Paulo State) was chosen because a previous study about the vegetal species variety in this region carried out by Prof. Mantovani and team [5].

Some Malvaceae species are considered tropical cosmopolitans, such as from Sida genus. Several species of this genus provide excellent textile bast fibers, which are very similar in qualities to the jute textile fiber [6]. The objective of the present study is present the physicochemical characterization of six Brazilian vegetal fibers: Sida rhombifolia L.; Sida carpinifolia L. f.; Sidastrum paniculatum (L.) Fryxell; Sida cordifolia L.; Malvastrum coromandelianum (L.) Gurck; Wissadula subpeltata (Kuntze) R.E.Fries. Respectively the two first species are from Brazilian Atlantic Forest biome and the four remaining from Brazilian Cerrado biome, despite of they are present in other regions of the planet.

\section{Material and methods}

The specimens of Sida rhombifolia L and Sida carpinifolia L. f. were collected in the region of Ecological Park of Tietê (São Paulo city - SP - Brazil), Brazilian Atlantic Forest biome. Adult specimens were collected totally. The central GPS position was S $23^{\circ} 28^{\prime} 59.5^{\prime \prime} \mathrm{W} 46^{\circ} 30^{\prime} 11.7^{\prime \prime}$ and the prospection radius $500 \mathrm{~m}$. The specimens of Sidastrum paniculatum (L.) Fryxell; Sida cordifolia L.; Malvastrum coromandelianum (L.) Gurck; Wissadula subpeltata (Kuntze) R.E.Fries were collected in the region of District of "Cachoeira de Emas" (Pirassununga city - SP - Brazil), Brazilian Cerrado biome. Adult specimens were collected totally. The central GPS position was S $21^{\circ} 56^{\prime} 38.6^{\prime \prime} \mathrm{W} 47^{\circ} 22^{\prime} 33.0^{\prime}$ and the prospection radius 1,000 m. Both collections were made with license of Brazilian Environment Institutes IBAMA and COTEC.

The stems of these species were retted in water at $37 \mathrm{oC}$ for 20 days. The fibers were tested in order to determine tensile rupture strength, tenacity, elongation, Young's modulus, cross microscopic structure, Scanning Electronic Microscopy (SEM), regain, combustion, the $\mathrm{pH}$ of the aqueous extract, acid, alkali, organic solvent and cellulase effects, Differential Scanning Calorimetry (DSC) and Thermogravimetric Analysis (TGA). The assays were performed at 20oC and 65\% relative humidity (ABNT NBR ISO 139:2005) [7] [8].

Tensile properties of the fibers (rupture strength, tenacity, elongation and Young's modulus), from the samples obtained from retting process, were determined according to ASTM D 3 822-2001 employing tester machine Instron (model 5569, Norwood, USA). Formerly, in order to determinate 
tenacity (strength value shared by count number) fiber fineness (linear density or count number) was calculated in terms of TEX, defined as the weight in grams per 1,000 m of the fiber, by weighing a known length of the fiber. A gauge length of $25 \mathrm{~mm}$, automatic pre-tension and crosshead speed of $50 \mathrm{~mm} / \mathrm{min}$ were employed. Cross microscopy structures were performed according to ABNT NBR 13538-1995. They were carried out in stereo-microscope coupled to a video camera in order to obtain digital images and cell diameter. These images were captured and processed by Video Analyzer 2000 system (Mesdan, Italy). Nova NanoSEM 200 Scanning Electron Microscope (FEI, USA) was used to investigate the morphological characteristics of individual fibers and fiber bundles. For SEM observation, the fibers were laid down on stub using a conductive carbon tape and were sputter-coated with gold palladium prior to observations.

Regain determinations were performed according the method adapted from ISO/TR 6741-4: 1987. Percent Moisture Regain (or "Regain") is defined as the weight of water calculated as a percentage of dry weight. Combustion qualitative tests were performed in order to determine combustion (burning, melting or shrinking of the fiber), flame, ash color and smell produced. The $\mathrm{pH}$ of the aqueous extracts was carried out according to AATCC 81-2001 and ASTM D 2165-90. A $0.1 \mathrm{~N} \mathrm{NaCl}$ solution with $\mathrm{pH}$ between 6.2 and 7.0 was boiled with the samples and a blank test was also performed.

The $\mathrm{pH}$ values were determined before and after boiling employing a bench pHmeter (model IRDA, Metrohm, Swiss). Acid effect on fibers was tested immersing the samples into $0.01 \mathrm{~N}$ and $0.1 \mathrm{~N} \mathrm{H} 2 \mathrm{SO} 4$ solutions during 60 minutes at room temperature $(20 \mathrm{oC})$. The fibers were weight before and after the treatment and damages determined visually. In similar way, alkali effect was determined employing $1 \mathrm{~N}$ and 7.5 N NaOH solution and organic solvent effect, immersing samples during $24 \mathrm{~h}$ in "Varsol" (Esso Standard of Brazil. Near composition: 18\% aromatic hydrocarbons, $40 \%$ naphthenic hydrocarbons and $42 \%$ paraffinic compounds). Cellulase effect on fibers were determined employing Aspergillus niger cellulase (Sigma-Brazil, code Sigma C1184, CAS no 901254-8, EC no 232-734-4) $1.0 \mathrm{~g} / \mathrm{L}(\mathrm{w} / \mathrm{v})$ concentration diluted in $0.1 \mathrm{M} \mathrm{KH} 2 \mathrm{PO} 4$ and $18 \mu \mathrm{m}$ EDTA, $\mathrm{pH} 8.0,4 \mathrm{oC}$. The fibers were treated at $55 \mathrm{oC}$ during 60 minutes. They were weight before and after the treatment and damages determined visually. DSC (Digital Scanning Calorimetry) tests were performed on Mettler Toledo equipment (Mettler Star SW 8.10. USA), with temperature from $0^{\circ} \mathrm{C}$ to $450{ }^{\circ} \mathrm{C}$ and heating rate of $10{ }^{\circ} \mathrm{C} / \mathrm{min}$. TGA (Thermogravimetric analysis) tests were performed in a TGA Q500 (TA Instruments, USA), with nitrogen at test temperature from $30 \mathrm{oC}$ to $800 \mathrm{oC}$ and heating rate of $30 \mathrm{oC} / \mathrm{min}$.

\section{Results and discussion}

\section{Tensile properties}

The results obtained in tests carried out on universal tester machine are presented in Table 1. Comparing the tenacity and Young's modulus values for studied species (Table 1) with the known textile fibers values (Table 2), for three species studied (Sida carpinifolia L. f.; Sidastrum paniculatum (L.) Fryxell; Wissadula subpeltata (Kuntze) R.E.Fries) the tenacity and Young's modulus values are comparable to the known textile fibers [7] [8]. For the other three ones (Sida rhombifolia L.; Sida cordifolia L.; Malvastrum coromandelianum (L.) Gurck) their tensile values are inferior to the known textile fibers respective values. Some of the studied species have employability in handicrafts and furthermore their tensile tests results are promising for employing these fibers as textile raw material or composite reinforcement. 
Table 1. Results of assays performed in a tester machine. The values are expressed of average of 20 determinations, respective standard deviation and variation coefficient.

\begin{tabular}{|c|c|c|c|c|c|}
\hline Species & $\begin{array}{c}\text { Count } \\
\text { Number } \\
\text { (tex) }\end{array}$ & $\begin{array}{l}\text { Rupture } \\
\text { Strength } \\
\text { (N) }\end{array}$ & $\begin{array}{l}\text { Tenacity } \\
\text { (cN/tex) }\end{array}$ & $\begin{array}{c}\text { Elongation } \\
(\%)\end{array}$ & $\begin{array}{c}\text { Young's } \\
\text { modulus } \\
(\mathrm{N} / \mathrm{tex})\end{array}$ \\
\hline Sida rhombifolia $\mathrm{L}$. & $559 \pm 327(59 \%)$ & $115 \pm 39(34 \%)$ & $14 \pm 6(42 \%)$ & $3.5 \pm 0.7(19 \%)$ & $9.4 \pm 2.7(29 \%)$ \\
\hline Sida carpinifolia L. $f$. & $183 \pm 41(22 \%)$ & $140 \pm 29(21 \%)$ & $24 \pm 8(34 \%)$ & $3.6 \pm 0.5(14 \%)$ & $13 \pm 3(21 \%)$ \\
\hline Sidastrum paniculatum (L.) Fryxell & $294 \pm 88(30 \%)$ & $259 \pm 81(31 \%)$ & $20 \pm 9(46 \%)$ & $4.8 \pm 1.2(26 \%)$ & $8.5 \pm 2.1(25 \%)$ \\
\hline Sida cordifolia $\mathrm{L}$. & $535 \pm 237(44 \%)$ & $266 \pm 71(27 \%)$ & $12 \pm 4(32 \%)$ & $3.9 \pm 1.0(25 \%)$ & $7.2 \pm 1.8(25 \%)$ \\
\hline Malvastrum coromandelianum (L.) Gurck & $311 \pm 62(20 \%)$ & $170 \pm 54(31 \%)$ & $11 \pm 4(39 \%)$ & $3.7 \pm 1.0(27 \%)$ & $7.9 \pm 2.0(25 \%)$ \\
\hline Wissadula subpeltata (Kuntze) R.E.Fries & $433 \pm 371(86 \%)$ & $171 \pm 55(32 \%)$ & $20 \pm 7(34 \%)$ & $3.5 \pm 0.7(19 \%)$ & $12 \pm 2(15 \%)$ \\
\hline
\end{tabular}

Table 2. Tenacity, elongation and Young's modulus values for species of recognized textile employability, glass and steel.

\begin{tabular}{llccc}
\hline Fibers & $\begin{array}{c}\text { Tenacity* } \\
\text { (cN/tex) }\end{array}$ & $\begin{array}{c}\text { Elongation* } \\
\mathbf{( \% )}\end{array}$ & $\begin{array}{c}\text { Young's } \\
\text { modulus* } \\
\text { (N/tex) }\end{array}$ \\
\hline Natural & Cotton** & $26.5-43.3$ & $3-7$ & $5.3-6.2$ \\
Fibers & Mercerized cotton & 30.0 & 7 & ---- \\
& Flax** & $23.0-68.0$ & $2.7-3.3$ & 15.5 \\
& Hemp & $51.2-60.0$ & 1.8 & 19.4 \\
& Jute** & $26.5-51.2$ & $1.7-2.0$ & 17.9 \\
& Abaca & $53.0-66.2$ & $2-3$ & 17.0 \\
& Ramie & 48.6 & $3-7$ & 16.2 \\
& Sisal & $35.3-44.1$ & $2-3$ & 12.4 \\
\hline Synthetic & Nylon 6.6 & $40.6-52.1$ & $24-40$ & $1.1-2.2$ \\
& Polyester & $38.8-44.1$ & $14-25$ & $1.6-3.2$ \\
& Polyethylene & $39.7-70.6$ & $20-80$ & $0.5-0.9$ \\
& Polypropylene & $35.3-61.8$ & $15-30$ & $1.1-4.1$ \\
& Glass & $53.0-64.5$ & 3.4 & $15.6-19.0$ \\
& Steel & 31.0 & 8 & 3.9 \\
\hline
\end{tabular}

* Values adapted from Kaswell [8].

** According to Reddy and Yang [9], Young's modulus of cotton, flax and jute are respectively 4.9, 17.9 and 17.2 N/tex (the values were adapted to the units of present study).

\section{Cross and SEM microscopies}

The cross-sectional and SEM microscopies of studied species are presented in Figure 1. For comparison purposes, cross-sectional microscopies of jute, sisal, abaca and hemp are presented in Figure 2. Comparing the images observed in Figures 1 and 2 the cross microscopies of fibers of this study match with other ones of recognized textile employability. The porosity and fibrilar structure of fibers are shown in SEM microscopies.

Despite of the similarities in the cross sections of studied species here and that ones from fibers of recognized textile employability, it cannot conclude, only through microscopic examination of their cross sections, the possible type of application for certain fiber. For this purpose there is the necessity of a combined analysis of results from other physical and chemical tests. However, examination of cross sections by optical microscopy also is useful to evaluate the integrity of fiber cellular structure and the adequacy of retting time for the extraction of the fibers. In the case of ultra-retting (when the excessive maceration makes the fibers brittle and weak) the damage to cellular structures is visible such as deformation of cell shape or forming large holes [10]. In the present study, the cross microscopies corresponding to the species analyzed showed the full integrity of cell structures. This means that the retting process time was suitable for extraction of these fibers. As shown in Table 3, all cell diameter values obtained for species in this study (with 
averages ranging from 9 to $16 \mu \mathrm{m}$ ) are compatible with the values of species of recognized textile employability.

According to Reddy and Yang [9], the unit cell size ranges from 12.0 to $25.0 \mu \mathrm{m}$ for cotton, 5.0 to $76.0 \mu \mathrm{m}$ for flax and from 15.0 to $25.0 \mu \mathrm{m}$ for jute.

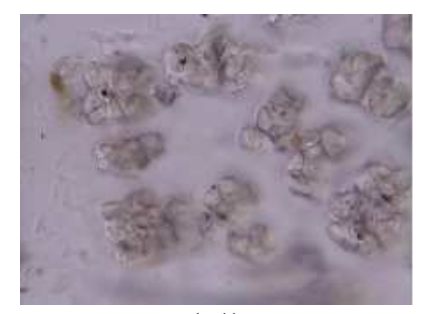

(a1)

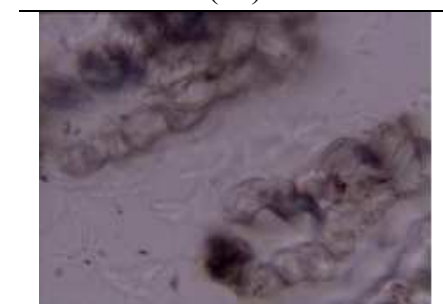

(b1)

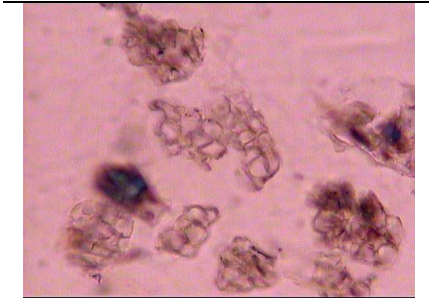

(c1)

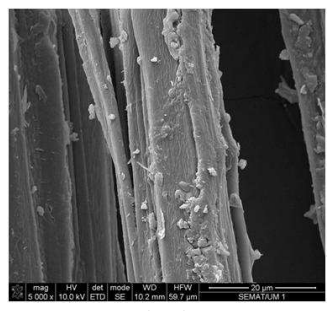

(a2)

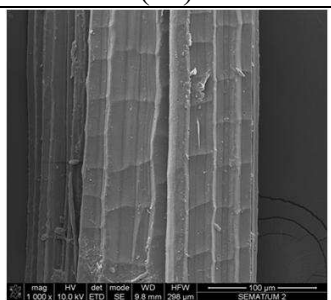

(b2)

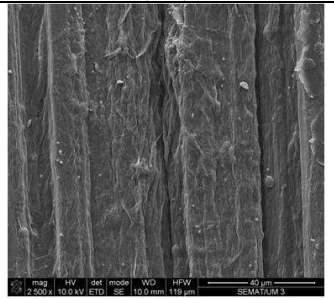

(c2)

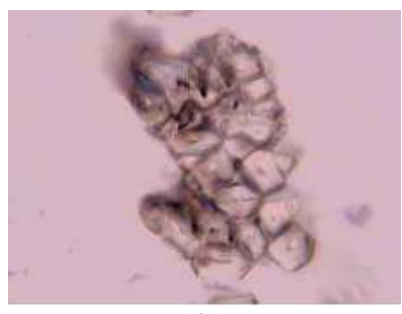

(d1)

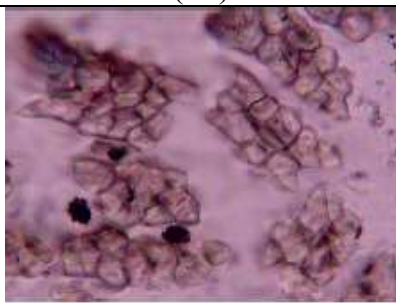

(e1)

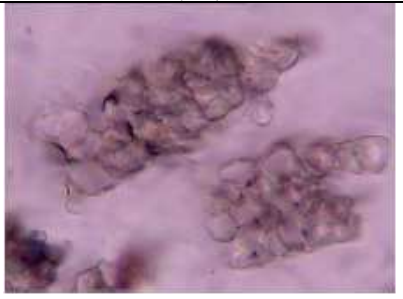

(f1)

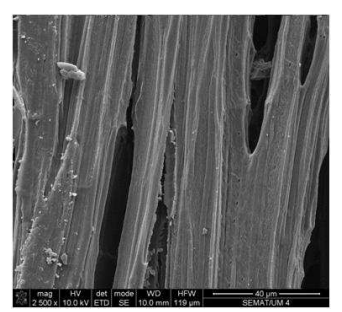

$(\mathrm{d} 2)$

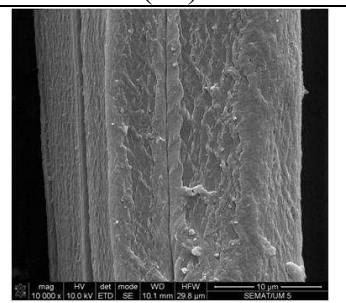

(e2)

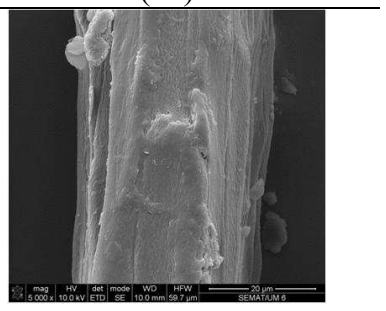

(f2)

Figure 1. Cross microscopic structure and Scanning Electronic Microscopy (SEM): (a) Sida rhombifolia L.; (b) Sida carpinifolia L. f.; (c) Sidastrum paniculatum (L.) Fryxell; (d) Sida cordifolia L.; (e) Malvastrum coromandelianum (L.) Gurck; (f) Wissadula subpeltata (Kuntze) R.E.Fries

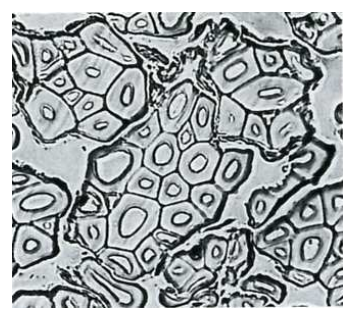

(a)

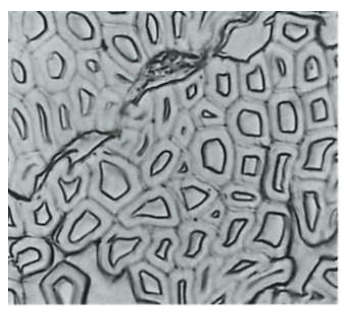

(b)

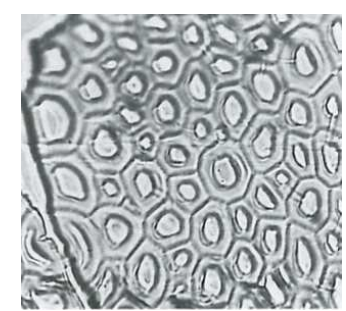

(c)

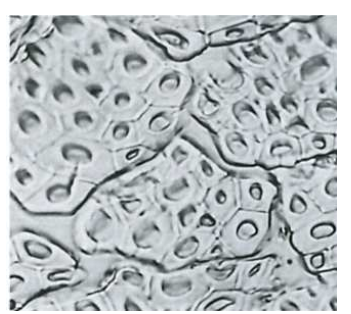

(d)

Figure 2. Cross-sectional microscopies (500x magnification): (a) jute, (b) sisal (c) abaca, (d) hemp [11].

\section{Regain determinations}

The values of regain are expressed in Table 4. Regain values of the studied species are consistent with other ones of recognized textile employability cellulosic fibers. Namely: cotton $8.5 \%$; mercerized cotton - $10.3 \%$; flax - 12\%; hemp - from 8 to $12 \%$; and jute - $13.8 \%$ [7] [8].

The physical structure of a fiber describes the amount of crystalline (ordered) and amorphous (disordered) material, their orientation to the fiber axis and the size of the crystals present in a fiber. All celluloses, such as cotton, ramie and wood, have the same polymer and unit cell structures, but the fibers have greatly different properties [9]. Thus, it is possible that species in this study showed 
higher regain values have this characteristic more associated with the presence of non-cellulosic substances than a larger amount of amorphous in relation to crystalline material in its structure.

\section{Combustion qualitative tests}

No relevant information was obtained through this test. There was no particular feature of these fibers to allow identification related to any others. All observed characteristics are common to all cellulosic fibers (fiber burning, orange flame, grey ash and burned wood or paper smell).

\section{pH of the aqueous extracts}

The values of $\mathrm{pH}$ of the aqueous extract after boiling process are expressed in Table 3 . The initial $\mathrm{pH}$ (before boiling) for all samples was 6.35 and in blank test, after boiling, 6.51 .

Table 3. Comparison of microscopy patterns of studied species to others from recognized textile employability and values of cell diameter expressed of average of five determinations, respective standard deviation and variation coefficient. In addition, values of regain (\%), $\mathrm{pH}$ of the aqueous extract after boiling and weight variation due cellulase treatment (\%).

\begin{tabular}{|c|c|c|c|c|}
\hline Species & $\begin{array}{c}\text { Cell diameter } \\
(\mu \mathrm{m})\end{array}$ & $\begin{array}{c}\text { Regain } \\
(\%)\end{array}$ & pH & $\begin{array}{c}\text { Cellulase } \\
\text { Treatment } \\
\text { Weight } \\
\text { variation } \\
(\%)\end{array}$ \\
\hline Sida rhombifolia $\mathrm{L}$. & $9 \pm 2$ & & 6.4 & -18.8 \\
\hline Sida carpinifolia L. f. & $14 \pm 5$ & 12.6 & $\begin{array}{l}4 \\
6.1\end{array}$ & -29.9 \\
\hline & & 12.0 & 7 & \\
\hline Sidastrum paniculatum (L.) Fryxell & $15 \pm 2$ & 10.5 & $\begin{array}{l}6.7 \\
5\end{array}$ & 3.1 \\
\hline Sida cordifolia $\mathrm{L}$. & $16 \pm 3$ & 13.4 & $\begin{array}{l}6.3 \\
9\end{array}$ & -1.2 \\
\hline Malvastrum coromandelianum (L.) Gurck & $9 \pm 1$ & 14.4 & $\begin{array}{l}6.3 \\
8\end{array}$ & -2.6 \\
\hline Wissadula subpeltata (Kuntze) R.E.Fries & $11 \pm 1$ & 14.0 & $\begin{array}{l}6.4 \\
5\end{array}$ & -2.2 \\
\hline Sida rhombifolia $\mathrm{L}$. & $9 \pm 2$ & 12.6 & $\begin{array}{l}6.4 \\
4 \\
\end{array}$ & -18.8 \\
\hline
\end{tabular}

*Species that suffered damages or degradation in its structure due the treatment.

According results showed in Table 3, all fibers in the present study did not change the saline solution $\mathrm{pH}$ during the boiling process. The only two exceptions were Sida carpinifolia L. f. (acidified slightly the $\mathrm{pH}$ ) and Sidastrum paniculatum (L.) Fryxell (basified slightly the $\mathrm{pH}$ ), being probable the presence of a little fraction of pectin or residues constituted by other impurities in these species could have led to this slight change on the saline solution $\mathrm{pH}$.

\section{Acid, alkali and organic solvent treatment effects}

The values of weight variation due acid, alkali and organic solvent treatment are expressed in Table 4. The samples no suffered damage and/or degradation visible like as darkening or burning of the fibers. 
Table 4. Values of weight variation (\%) due acid, alkali and organic solvent treatment.

\begin{tabular}{|c|c|c|c|c|c|}
\hline Species & $\begin{array}{c}\text { Weight } \\
\text { Variation } \\
\mathrm{H}_{2} \mathrm{SO}_{4} \\
\mathbf{0 . 0 1 N} \\
(\%) \\
\end{array}$ & $\begin{array}{c}\text { Weight } \\
\text { Variation } \\
\mathrm{H}_{2} \mathrm{SO}_{4} \\
\mathbf{0 . 1 N} \\
(\%) \\
\end{array}$ & $\begin{array}{c}\text { Weight } \\
\text { Variation } \\
\text { NaOH } \\
1 \mathbf{N} \\
(\%) \\
\end{array}$ & $\begin{array}{c}\text { Weight } \\
\text { Variation } \\
\mathrm{NaOH} \\
7.5 \mathrm{~N} \\
(\%) \\
\end{array}$ & $\begin{array}{c}\text { Weight } \\
\text { Variation } \\
\text { Organic } \\
\text { solvent } \\
(\%) \\
\end{array}$ \\
\hline Sida rhombifolia $\mathrm{L}$. & $8.5^{*}$ & 45.2 & 0.0 & 33.3 & -2.0 \\
\hline Sida carpinifolia $L . f$. & $9.0^{*}$ & 6.7 & 3.1 & -15.1 & 0.9 \\
\hline Sidastrum paniculatum (L.) Fryxell & 2.0 & 23.9 & 7.5 & -14.0 & -0.6 \\
\hline Sida cordifolia L. & 43.8 & 40.6 & 3.1 & -6.5 & 0.0 \\
\hline Malvastrum coromandelianum (L.) Gurck & -1.9 & -1.4 & 2.7 & -2.5 & 0.0 \\
\hline Wissadula subpeltata (Kuntze) R.E.Fries & 3.3 & -1.8 & 4.2 & -7.5 & 1.7 \\
\hline
\end{tabular}

*Species that suffered damages or degradation in its structure due the treatment.

Generally, cellulose fibers cannot resist acids, especially those ones of mineral origin, such as sulfuric acid [12] [13]. It was observed that there was a trend in the results of both acid treatments on which the samples maintained or gained weight after these treatments. It is possible that acid action, while eliminating non-cellulosic components (hemicellulose and lignin), have exposed more the cellulose structures of such fibers, which are more hydrophilic. Furthermore, acid treatments acting on the physical and chemical structures of the fibers, especially with respect to amorphous and crystalline regions of cellulose, may cause to an increase in the amorphous regions leading to an increased hydrophilicity.

Most of processes in the textile industry are alkaline [14]. The alkaline pretreatment of fiber aims to increase the surface area of the biomass and to reduce the crystallinity of the cellulose. While the acid treatment promotes the hydrolysis of hemicellulose layer, the alkaline treatment promotes the removal of part of the lignin layer leaving intact hemicellulose, which needs hemicellulolytic enzymes to be degraded. The use of alkaline pretreatment requires moderate temperatures and pressures (when compared to the acid treatment) and is the removal of lignin biomass promoting greater reactivity of the fiber. By promoting a strong delignification of biomass, the alkalis are used in the treatment of materials with reduced lignin content, for example, agroindustrial residues [15] [16]. In the present study, according to the data expressed in Table 4, no significant weight changes were observed when the fibers were treated with $\mathrm{NaOH} 1 \mathrm{~N}$. This treatment gave to the studied fibers a beneficial effect which increases their transverse dimensions (swelling), increased gloss and smoothness of their surfaces (visually and tactually perceived) (data not shown). On the other hand, there was a trend in the results of alkaline treatment employing $\mathrm{NaOH} 7.5 \mathrm{~N}$ in which the samples lost slightly weight after them, exception Sida rhombifolia L., which gained weight after the treatment. Thus, it is possible to cogitate that the alkaline action has caused a delignification more intense than acid treatments and thus promoted the mass loss of samples subjected to contact with caustic soda. Thus is possible to cogitate that these species present resistance to alkaline action and consequent delignification. In this way, this characteristic could be appropriated to employ them for example in cement composites [17].

There was no significant variation in the mass of the samples before and after treatment with organic solvent. However for species that have not changed their mass, a potential application more significant than dry cleaning processes, is the possibility of their employ in plastic composites with thermoset matrices (epoxy, polyester, phenolic, etc.). In these matrices, the polymerization occurs through the removal of the solvent [18]. In this way, it is interesting that the reinforcing fibers are not affected by the solvent during the manufacturing process of the composite as the preliminary results presented in this study. 


\section{DSC and TGA tests}

DSC tests were performed with the original samples at room temperature and also with samples taken from vacuum oven. By TGA tests were obtained graphs presenting the weight loss curves and the curve of the derivative. Figure 3 shows DSC and TGA graphs taking as example the results generated for Sida carpinifolia L. f.. For comparative purposes, the DSC and TGA tests were also performed with fibers of Cannabis sativa L., because it is a well known cellulosic fiber.

By comparison of results in both methodologies was possible to perform a preliminary determination of hemicellulose, a-cellulose and lignin contents for the studied fibers as shown in Table 5.

From the results shown in Table 5 it is possible to see that the results are very similar between them and with the results of hemp tested under the same conditions. Hemp bundle bast fibres were found to contain little amounts of hemicellulose and lignin [19] similar to the results presented in Table 5, despite of in the present study the hemp hemicellulose was not determined.

In comparison with the known fibers, as sisal, coconut, cotton and jute, the results shown in Table 5 have similar values. The values of hemicellulose for sisal and jute are 10.1 and 13.6 respectively [20]. These values are very similar to the studied fibers, particularly Sida rhombifolia L. (14.3\%), Sidastrum paniculatum L. F. (14.6\%), Malvastrum coromandelianum (L.) Gurck $(11.6 \%)$ and Wissadula subpeltata (Kuntze) R.E.Fries (11.6\%). However, all fibers analyzed in this study presented higher hemicellulose content than the hemicellulose content of cotton [19]. This could be explained by the high content of cellulose in cotton, which also belongs to family Malvaceae, and by the fact that hemicellulose content is normally higher in stem fibers (as the studied ones here) than seed fibers (as cotton).

DSC results (Table 5) showed sequential characteristic peaks for hemicellulose (beginning near $300^{\circ} \mathrm{C}$ ), cellulose (beginning near $360^{\circ} \mathrm{C}$ ) and lignin (beginning near $420^{\circ} \mathrm{C}$ ). These are close to that ones for experimentally determined for hemp fiber (exception hemicellulose peak, that was not detected for this fiber in the present study) and confirmed in literature [21]. It is worth of mention, as presented above, that in the present study: i) the species have not altered significantly the $\mathrm{pH}$ of saline solution; ii) all of them showed no mass change in solvent for $24 \mathrm{~h}$; iii) despite of mass variation for some of them, the studied species have suffered no damages in acid, alkali or cellulase treatment.

There are a significant number of studies about hemp employment as reinforcement in thermoset and thermoplastic composites, based in its mechanical and thermal properties [22, 23]. On other hand, besides the possibility of thermoset composites production employing the present studied fibers, taking in account the fusion point $\left(165^{\circ} \mathrm{C}\right)$ and extrusion process temperature $\left(250^{\circ} \mathrm{C}\right)$ of polypropylene [24], it is plausible the hypothesis of production of composites with this matrix and the present studied fibers as reinforcement. In this way, even considering the inferior tensile results, but also the similarity between DSC patterns of studied Malvaceae fibers and hemp, these natural raw materials could offer possibilities for developing new products and processes in medium resistance composite production. 


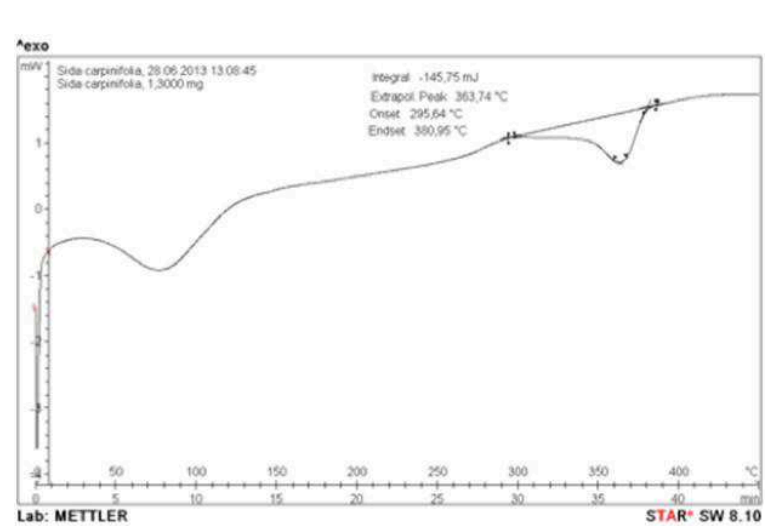

(a)

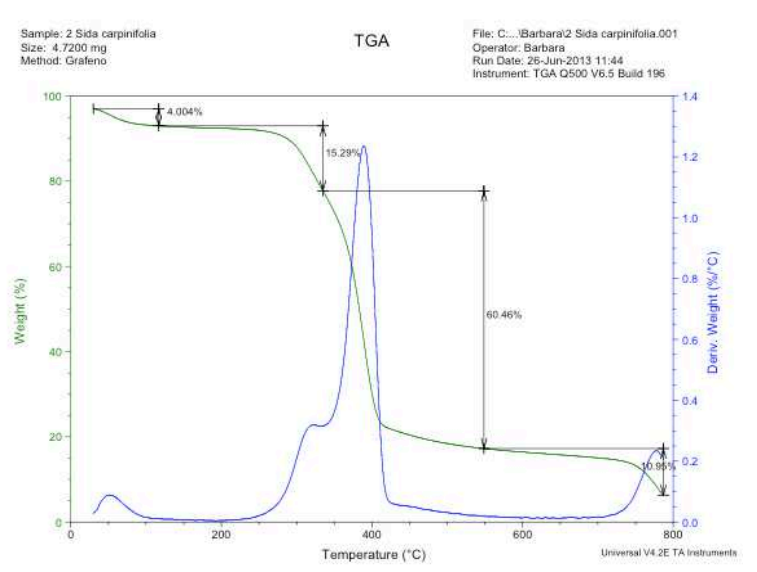

(b)

Figure 3. Graphs generated for Sida carpinifolia L. f.: (a) DSC (Mettler Toledo, Mettler Star SW 8.10, USA); (b) TGA (TGA Q500, TA Instruments, USA)

Table 5. Determination of hemicellulose, a-cellulose and lignin contents through DSC/TGA analysis

\begin{tabular}{|c|c|c|c|c|c|c|c|c|c|}
\hline Species & 莺导 & 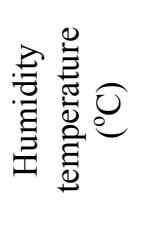 & 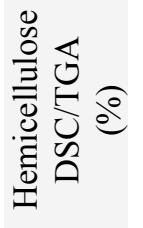 & 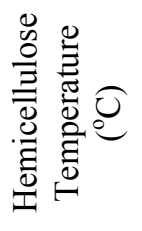 & 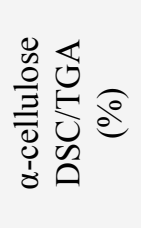 & 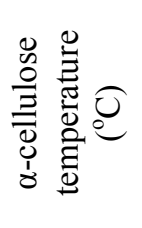 & $\underset{0}{\stackrel{0}{\equiv}} \stackrel{0}{0}$ & . & 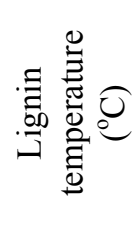 \\
\hline Sida rhombifolia & 5.1 & 100 & 14.3 & 285 & 55.7 & 366 & $\begin{array}{c}70 . \\
0 \\
\end{array}$ & 20.7 & 425 \\
\hline Sida carpinifolia & 4.0 & 100 & 15.3 & 296 & 60.5 & 364 & $\begin{array}{c}75 . \\
8 \\
\end{array}$ & 11.0 & 421 \\
\hline $\begin{array}{c}\text { Sidastrum } \\
\text { paniculatum }\end{array}$ & 3.7 & 100 & 14.6 & 295 & 59.5 & 365 & $\begin{array}{c}74 . \\
0 \\
\end{array}$ & 15.7 & 421 \\
\hline Sida cordifolia L. & 4.3 & 100 & 9.9 & 306 & 60.6 & 364 & $\begin{array}{c}70 . \\
5 \\
\end{array}$ & 20.4 & 421 \\
\hline $\begin{array}{c}\text { Malvastrum } \\
\text { coromandelianum }\end{array}$ & 3.5 & 100 & 11.6 & 337 & 57.4 & 366 & $\begin{array}{c}69 . \\
1 \\
\end{array}$ & 26.6 & 421 \\
\hline Wissadula subpeltata & 4.4 & 100 & 11.6 & 287 & 56.1 & 360 & $\begin{array}{c}67 . \\
7\end{array}$ & 16.0 & 420 \\
\hline Cannabis sativa $\mathrm{L}$. & 4.8 & 100 & n.d. & n.d. & 65.7 & 362 & $\begin{array}{c}65 . \\
7\end{array}$ & 17.2 & 421 \\
\hline
\end{tabular}

\section{Conclusions}

For three species studied (Sida carpinifolia L. f.; Sidastrum paniculatum (L.) Fryxell; Wissadula subpeltata (Kuntze) R.E.Fries) the tenacity and Young's modulus values are comparable to the known textile fibers (cotton, flax, ramie, etc). For the other three ones their tensile values are inferior to the known textile fibers. The cross microscopies of fibers of this study matches with other ones of recognized textile employability. Regain values and combustion results (flame, color and odor) are similar to other cellulosic fibers. The species no alter significantly the $\mathrm{pH}$ of saline solution. All of them showed no mass change in solvent for $24 \mathrm{~h}$. Despite of mass variation for some of them, the studied species have suffered no damages in acid, alkali or cellulase treatment. DSC results showed sequential characteristic peaks for hemicellulose, cellulose and lignin close to that ones for experimentally determined for hemp fiber. In this way, besides the possibility of thermoset composites production, taking in account the fusion point $\left(165^{\circ} \mathrm{C}\right)$ and extrusion process temperature $\left(250^{\circ} \mathrm{C}\right)$ of polypropylene, it is plausible the hypothesis of production of composites 
with this matrix and the studied fibers as reinforcement. In this way, even considering the inferior tensile results, but also the similarity between DSC patterns of studied Malvaceae fibers and hemp, these natural raw materials could offer possibilities for developing new products and processes in medium resistance composite production. In this way, these new natural raw materials could offer possibilities for developing new products and processes.

\section{Acknowledgements}

FAPESP ("Fundação de Amparo à Pesquisa do Estado de São Paulo"), CAPES (Coordenação de Aperfeiçoamento de Pessoal de Nível Superior) and CNPq ("Conselho Nacional de Desenvolvimento Científico e Tecnológico") are gratefully acknowledged. The authors would also like to thank Mr. Ervin Sriubas Jr. and Kellinton José Mendonça Francisco for their technical support.

\section{Permission for publication}

It is the responsibility of the author (s) the citation of organs and / or institutions as well as the content of their articles, and editors and visual designers reserved the right to modify the presentation of figures, tables and equations aiming to standardize the text.

\section{References}

[1] Santos, P. A.; Marcia A.S.; Spinacé, K. K.G.; Fermoselli, M.; De Paoli, A. Polyamide-6/Vegetal Fiber Composite Prepared By Extrusion And Injection Molding, Composites - Part A (Issn 1359835x), V. 38, P. 2404-2411, 2007.

[2] Silva, R. S. Compósito de Resina Poliuretano Derivada de Óleo de Mamona e Fibras Vegetais. 2003. 139 p. PhD Thesis (PhD in Sciences and Engeneering of Materials - Escola de Engenharia de São Carlos) - University of São Paulo. São Carlos (SP - Brazil), 2003.

[3] Tabarelli, M.; Aguiar, A. V.; Ribeiro, M. C.; Metzger, J. P.; Peres, C. A. Prospects for biodiversity conservation in the Atlantic Forest: lessons from aging human-modified landscapes. Biological Conservation (ISSN 0006-3207), v. 143, n.10, p. 2328-2340, 2010.

[4] Oliveira, P. S.; Marquis, R. J. The Cerrados of Brazil: Ecology and Natural History of a Neotropical Savanna. New York city: Columbia University Press, 2002. ISBN 0-231-12043-5.

[5] Batalha, M.A.; Aragaki, S.; Mantovani, W. Florística do Cerrado em Emas (Pirassununga, SP). Boletim Botânico da USP (ISSN 0302-2439), v. 16, p. 49-64, 1997.

[6] Medina, J. C. Plantas Fibrosas da Flora Mundial. Impresso pelo Instituto Agronômico de Campinas, 1959. 913 p.

[7] Saville, B.P. Physical testing of textiles. Cambridge: The Textile Institute Woodhead Publishing Limited, 2007. ISBN 978-1-85573-367-1.

[8] Kaswell, E. R. Wellington Sears Handbook of Industrial Textiles. Massachusetts Institute of Technology (MIT) e Wellington Sears Company, Library of Congress Catalogue Number 63-14165, Cambridge, United States, 1963.

[9] Reddy, N.; Yang, Y. Properties and potential applications of natural cellulose fibers from cornhusks. Green Chemistry (ISSN 1463-9262), v. 7, p. 190-195, 2005.

[10] Gañán, P.; Zuluaga, R.; Velez, J.M.; Mondragon, I. Biological natural retting for determining the hierarchical structuration of banana fibers. Macromolecular Science (ISSN 0022-2348), v. 4, p. 978-983, 2004.

[11] Maluf, E.; Kolbe, W. Manual - Dados técnicos para a indústria têxtil. $2^{\mathrm{a}}$ ed. São Paulo: IPT Instituto de Pesquisas Tecnológicas e ABIT - Associação Brasileira da Indústria Têxtil e da Confecção, 2003. ISBN 85-09-00124-3. 
[12] Ribeiro, L.G.; Andrade Filho, J. Introdução à Engenharia Têxtil. v. 1 (208 p.), v. 2 (214 p.), v.3. (196 p.) SENAI, Rio de Janeiro, Brasil (1987).

[13] Araújo, M.; Melo E Castro, E.M. Manual de Engenharia Têxtil. v. 1 e v. 2. (1648 p.), Fundação Caloustre Gulbekian, Lisboa, Portugal (1984).

[14] Salem, V.; De Marchi, A.; Menezes, F.G. O beneficiamento têxtil na prática. $1^{\text {a }}$ ed. 189 p. Golden Química do Brasil, São Paulo, Brasil (2005).

[15] Pietrobon, V. C. Hidrólise do bagaço de cana-de-açúcar pré-tratado com ácido e álcali utilizando enzimas microbianas comerciais. 2008. 66 p. McS Thesis (Mestrado em Agronomia, área de concentração Microbiologia Agrícola - Escola Superior de Agricultura "Luiz de Queiroz") University of São Paulo, Piracicaba, SP-Brazil (2008).

[16] Baudel, H. M. Workshop produção de etanol: pré-tratamento e hidrólise. Project of the research program in public policies. UNICAMP, 2006. Available from http://www.inovacao.unicamp.br/etanol/report/Hidrolise\%20Baudel\%20Apresenta\%E7\%E3o.pdf Accessed: 2012-09-06.

[17] Savastano Jr., H. Materiais à base de cimento reforçados com fibra vegetal: reciclagem de resíduos para a construção de baixo custo. 2000. 144 p. Associate Professor Thesis (Livre-Docência - Departamento de Engenharia de Construção Civil da Escola Politécnica da Universidade de São Paulo) - University of São Paulo, Brasil (2000).

[18] Wiebeck, H.; Harada, J. Plásticos de engenharia: tecnologia e aplicações. 350 p. Editora Artiber. ISBN: 9788588098275. São Paulo, Brasil (2005).

[19] Ouajai, S.; Shanks, R.A Composition, structure and thermal degradation of hemp cellulose after chemical treatments, Polymer Degradation and Stability (ISSN 0141-391), v. 89, n. 2, p. $327-$ $335,2005$.

[20] Leão, M. A. Fibras de Licuri: Um reforço alternativo de compósitos poliméricos. 2008. 109 p. $\mathrm{McS}$ Thesis (Mestrado do programa de pós-graduação em Engenharia Mecânica da Universidade Federal do Rio Grande do Norte) - University Federal of Rio Grande do Norte, Natal, RN - Brazil, 2008.

[21] Aziz, S. H.; Ansell, M. P. The effect of alkalization and fibre alignment on the mechanical and thermal properties of kenaf and hemp bast fibre composites: Part 1 - polyester resin matrix. Composites Science and Technology (ISSN 0266-3538), v. 64, p. 1219-1230, 2004.

[22] Panthapulakkal, S.; SAIN, M. Injection-Molded Short Hemp Fiber/Glass Fiber-Reinforced Polypropylene Hybrid Composites-Mechanical, Water Absorption and Thermal Properties. Journal of Applied Polymer Science (ISSN 1097-4628), v. 103, p. 2432-2441, 2007.

[23] Bourmaud, A.; Baley, C. Investigations on the recycling of hemp and sisal fibre reinforced polypropylene composites. Polymer Degradation and Stability (ISSN 0141-391), v. 92, p. 10341045, 2007.

[24] Manrich, S. Processamento de termoplásticos: rosca única, extrusão e matrizes, injeção e moldes. 431 p. Editora Artiber. ISBN: 9788588098305. São Paulo, Brasil (2005). 